\title{
Does government funding depoliticize non-governmental organizations? Examining evidence from Europe
}

\author{
ELIZABETH BLOODGOOD ${ }^{1 *}$ AND JOANNIE TREMBLAY-BOIRE ${ }^{2}$ \\ ${ }^{1}$ Department of Political Science, Concordia University, Quebec, Canada \\ ${ }^{2}$ Department of Political Science, University of Washington, Seattle, WA, USA
}

Prior work suggests that government funding can encourage non-governmental organizations (NGOs) to engage in political advocacy and public policy. We challenge this finding and examine two theoretical explanations for the dampening effect of government funding on NGO lobbying. First, donors are known to discipline NGO activity via an implicit or explicit threat to withdraw funding should the organization become too radical or political. Second, NGOs with more radical political agendas are less willing to seek or accept government funding for fear this will limit or delegitimize their activities. Using data from the European Union's Transparency Register, we find that the share of government funding in NGO budgets is negatively associated with lobbying expenditure. This effect is statistically significant and substantial, which provides a reason for concern about NGO resource dependence. Even when governments are motivated by honorable intentions, their financial assistance has the (unintended) effect of dampening NGOs' political activity.

Keywords: NGO; financing non-governmental organizations; European Union; lobbying

\section{Introduction}

Does government funding depoliticize non-governmental organizations (NGOs)? Prior work suggests that government funding can encourage NGOs to engage in political activity (Chaves et al., 2004; Child and Gronbjerg, 2007; Mahoney, 2008; Mosley, 2011; Lecy and Van Slyke, 2013). We present two explanations for the dampening effect of government funding, challenging this argument. ${ }^{1}$ Donors are known to discipline NGOs via implicit or explicit threats to withdraw funding should their activity become too radical. Increased government funding should thus moderate NGOs' political activity (McAdam, 1982; Ryan et al., 2002;

\footnotetext{
${ }^{1}$ NGOs are formal non-profit organizations, including associations, charities, foundations, and civil society organizations. This definition is consistent with section III of the EUTR (Interinstitutional Agreement on Establishment of Transparency Register L191/33-4; EUTR Compliance Guidelines, 2012: 8), ECOSOC's definition (ECOSOC, 1996/31/12), and the literature (Tallberg et al., 2013; Pallas and Uhlin, 2014). We exclude political parties, labor unions, corporations, religious organizations, and intergovernmental agreements. Business associations are included if non-profit, for example, Chambers of Commerce.
}

* E-mail: elizabeth.bloodgood@concordia.ca 
Berry, 2003). Scholars suggest that NGOs self-select funding based on their ideological and strategic profiles. Organizations wishing to engage in radical activities are less willing to accept government funding as this might limit their activities (Ostrander et al., 2005; Stroup, 2012). Thus, government funding should target less political NGOs, and more political NGOs want less government funding.

Using quantitative analysis, we find that the share of governmental funding in an NGO's budget is negatively associated with lobbying expenditure, suggesting that government funding depoliticizes NGOs. We make three contributions to understanding funding portfolios' effects on NGO activity. First, we expand analysis from the United States to Europe. Second, we help resolve contradictions in past research. By including the extent and source of government funding (national or international), we produce different relationships between government funding and NGO lobbying. Third, we find more support for government threat than NGO self-selection to explain the relationship between government funding and NGO lobbying expenditure.

This research has implications for NGO advocacy research and concrete consequences for public policy. While resource dependence can constrain NGO political activity, this relationship is more complicated than previously suggested. Our work suggests that governments' ability to 'purchase' civil society to contribute to public policy is limited (Medelson and Glenn, 2002; Steffek et al., 2008; Bexell et al., 2010; Dupuy et al., 2015). Politically active civil society groups need to be connected to the grassroots. Interest group scholars have identified group composition and internal decision-making as potential obstacles to reducing democratic deficits and improving popular representation of NGOs (Halpin, 2006; Greenwood, 2007; Steffek and Hahn, 2010; Saurugger, 2011). We add funding composition to concerns about internal governance. Even when governments have honorable intentions, their financial support has the unintended consequence of dampening NGOs' political activity. Scholars and practitioners should rethink how governments might foster politically active NGOs and the necessary conditions for NGOs to serve as effective representatives (Warleigh, 2001; Greenwood and Halpin, 2007; Sanchez Salgado, 2014).

\section{Argument}

We define political activity as 'any attempt to influence the decisions of any institutional elite on behalf of a collective interest' (Jenkins, 1987: 297). NGO political activities can range from public education to public protest. Lobbying includes insider and outsider tactics, such as meetings with policymakers, position papers, testimony before government bodies, press conferences, letter-writing campaigns, and grassroots mobilization (Mahoney, 2008). We define depoliticization as removing or restricting actors' ability to participate politically, including electoral 
processes and passage or implementation of policy at national or international levels (Jaeger, 2007). We observe depoliticization through reported lobbying expenditure: the less money an NGO spends on lobbying, the less politically active it is. We expect that, as the government share of NGO income rises, the share of resources spent on lobbying (proxy for political activity) will decline, particularly if the NGO receives funding from national sources. ${ }^{2}$

Our argument is based on an adversarial model of interest group politics from the American interest group literature. The European interest group literature has focused on the co-evolution of government policy and interest group activity as they work together through the policy cycle (Streeck and Schmitter, 1991; Ullman, 1999; Beyers et al., 2008). NGOs are networked with government via semi-formal institutional forums constructed to promote regularized consultation between peak interest associations and governments in a neo-corporatist fashion (Wilson, 1983; Sanchez Salgado, 2014). In contrast, the American literature emphasizes group formation and access to institutions, given the autonomous interests and resources of interest groups and government (Baumgartner and Leech, 1998; Cowles, 2003; Beyers et al., 2008; Coen and Richardson, 2009). In this adversarial model, interest groups fight to gain access to resources, information, and decision-making processes to influence policy toward their preferred positions (Crawford and Sobel, 1982; Lohmann, 1993; Austen-Smith, 1994). Government actors hold positions compatible with some groups, and even collaborate (Dür, 2008), but naturally find themselves opposed to other groups and stand to gain by denying them access and influence (Beyers et al., 2008). We assume that, while collaboration with NGOs has benefits in terms of expertise, ideas, and public support (Brown et al., 2012; Stroup, 2012; Lecy and Van Slyke, 2013), governments wish to discriminate among interest groups and shape NGO political activity.

Governments can direct NGO political activity by enacting regulations, visibly exercising influence. For example, Russia requires NGOs to report political activities and receipts of foreign money (ICNL, 2012; Dupuy et al., 2015). Anti-NGO regulations can create political problems in democratic systems with strong civil societies. A 2003 Australian bill proposing to ban NGOs engaged in advocacy from charitable status was withdrawn because of public criticism (Maddison, 2007). Governments can also use funding as a subtle means of discouraging lobbying. On average, $48 \%$ of NGO revenues in developed countries come from government sources. ${ }^{3}$ To the extent that NGOs need resources to operate, the possibility of

\footnotetext{
${ }^{2}$ Reported lobbying expenditure is a very narrow measure of advocacy (Berry, 2005) and misses important but hard to monetize activities, but it is consistent cross-nationally, captures advocacy activities of greatest concern to governments, and includes grassroots and professional efforts (Boris and MosherWilliams, 1998; Leech, 2006; Ruggiano and Taliaferro, 2012). Lobbying expenditure is more reliable than other measures because NGOs are required to report lobbying expenditure figures to governments.

${ }^{3}$ Johns Hopkins University Center for Civil Society Studies, http://ccss.jhu.edu/wp-content/uploads/ downloads/2013/02/Comparative-data-Tables_2004_FORMATTED_2.2013.pdf
} 
losing funding sends a strong signal. Freedom of action is limited without explicitly signaling government intent to reduce NGO political activity.

We identify two mechanisms that might drive depoliticization. First, donors can discipline NGO activity via implicit or explicit threats to withdraw funding should the organization become political. Resource dependence theory states that governments can control organizations by managing access to vital resources (Ruggiano and Taliaferro, 2012). If NGOs are not responsive to financially powerful actors, they will cease to exist (Beyers and Kerremans, 2007; Mitchell, 2012). In return for grants and tax advantages, states expect NGOs to deliver social services and implement government policies, not challenge them (Anheier et al., 1997; Sanchez Salgado, 2010; Neumayr et al., 2015). Government funding should thus reduce NGO political activity.

Second, NGOs may self-select their funding sources based on ideology and goals (Beyers et al., 2008). Organizations wishing to engage in more radical political activities are less willing to accept government funding for fear that this will limit or delegitimize them (Ebrahim, 2003; Ostrander et al., 2005). Humanitarian and health organizations require large, reliable funding sources, making them more likely to censor political activities (Mosley, 2011). Environmental, human rights, and social justice organizations, conversely, are argued to avoid governmental entanglements to maintain their autonomy and legitimacy as critics (Wells, 2001). Scholars thus expect issue area to affect NGOs' interest in advocacy and the composition of their funding (Boris and Mosher-Williams, 1998; Child and Gronbjerg, 2007; Stroup, 2012).

We expect funding by national governments to have a dampening effect and European Union (EU) funding to be enabling of NGO political activities. The EU has a mandate to encourage civil society to socialize new member states (Streeck and Schmitter, 1991; Mahoney and Beckstrand, 2011) and alleviate fears of a democratic deficit (Greenwood, 2007; Kohler-Koch and Finke, 2007; Steffek and Hahn, 2010; Commission of the European Communities, 2001). The costs and risks of NGO activism are lower at the supranational level: the arena is large and a diversity of issues and interests are represented. States can find sympathetic organizations to counter unfriendly ones. Within countries, governments are less likely to find countervailing organizations.

We argue that the dampening effect of public funding is stronger than the NGO self-selection effect, as more organizations across issues mix service and advocacy to accomplish their goals (Warleigh, 2001; Chaves et al., 2004; Stroup, 2012). We expect share of public financing to have a stronger and more significant relationship with lobbying expenditure than sector.

\section{Depoliticizing effects of government funding}

Depoliticization may come from government or NGOs, for normative or strategic reasons. According to the social movement literature, institutional patronage (foundation or government) protects elite interests by moderating social movements' 
activism. Three mechanisms - selection, professionalization, and threat - work to reduce NGO interest in, and ability to, engage in political behaviors.

Scholars suggest that foundations select and support moderate groups to prevent or reduce radical mobilization (McAdam, 1982; Haines, 1984). The 'paradigm of conflict' (Salamon, 2002) posits that a similar relationship exists between NGOs and government as the state seeks to maintain political control. The state, as resource provider and regulator, can deter NGO advocacy. ${ }^{4}$ Research has demonstrated that punishment is rare (Ryan et al., 2002), but NGO leaders are reluctant to 'bite the hand that feeds them' (Bass et al., 2007; Onyx et al., 2008). Even NGOs without government funding are afraid to jeopardize such funding in the future (Chaves et al., 2004). ${ }^{5}$ Regulatory complexity also contributes to NGOs' unwillingness to engage in advocacy (Berry, 2003; Bass et al., 2007). Governmentfunded NGOs are often subject to additional regulations and reporting requirements (Chaves et al., 2004; Berry, 2005). Leech (2006) and Berry and Arons (2003) find evidence that less politically active non-profits seek more federal funds and organizations receiving more federal funds engage in less lobbying.

Government funding may spur depoliticization by encouraging NGOs to become professionalized (Smith, 1999; Sanchez Salgado, 2010; Suarez, 2011; Klüver and Saurugger, 2013). Empirical studies of government-funded NGOs find evidence of increased bureaucratization and a shift from advocacy to service delivery (Gronbjerg, 1993; Smith and Lipsky, 1993; Anheier et al., 1997; Froelich, 1999; Smith, 1999). NGOs expend more resources on accounting, reporting, and auditing requirements (Anheier et al., 1997; Smith and Gronbjerg, 2006; Suarez, 2011; Verbruggen et al., 2011). Mosley (2012) also argues that increased government funding leads NGOs to advocate increasingly to secure funding ('selfpromotion') rather than for policy change. Smith and Lipsky (1993: 176) agree, noting 'nonprofits use advocacy to their advantage' to gain preferential treatment and community support.

Finally, governments can channel NGO activity by building 'organizational fields'. Group accreditation as a funding requirement 'offer[s] the prospect of a regulatory tool with which to shape the qualities valued in groups. Each of the benefits of expertise, democratic legitimacy, and implementation can be emphasized or de-emphasized' (Greenwood and Halpin, 2007: 194). For example, advocacy outside of the official policy process is strongly discouraged in Japan, while outsider advocacy dominates in the United Kingdom and insider advocacy is seen as more appropriate in the United States (Stroup, 2012). Resource dependence enables coercive isomorphism

\footnotetext{
${ }^{4}$ Chaves et al. (2004) counter that the government is unlikely to take drastic measures because it depends on NGOs for service delivery. Mutual dependence could encourage NGOs to lobby more, not less (Onyx et al., 2008), but only if NGOs are aware of this mutual dependence.

5 NGO concerns are not necessarily a result of explicit government coercion; 'government threat' may be implicit. NGOs' need for resources may make them feel vulnerable and subservient, regardless of the government's actions.
} 
by government funders demanding NGO compliance, for example with reporting requirements (Sanchez Salgado, 2010; Verbrauggen et al., 2011; Ruggiano and Taliaferro, 2012). Government funding also produces normative isomorphism as NGOs adopt behaviors conforming to the values of government funders to maintain legitimacy (Schmid et al., 2008; Klüver and Saurugger, 2013).

NGOs may be responsible for depoliticization. Certain NGOs, particularly human rights and environmental NGOs, refuse government funding to maintain their autonomy and credibility as government critics (Ebrahim, 2003; Ostrender et al., 2005; Stroup, 2012). Anheier et al. (1997: 195) find that advocacy organizations are largely funded by private sources. Moulton and Eckerd (2012) also link NGOs' funding streams to organizational values. For instance, Oxfam America prioritizes responsiveness to beneficiaries, and government donors may demand that Oxfam prioritize their goals instead (Stroup, 2012). Other NGOs avoid government funding because they 'simply lack the interest or administrative structure' to administer grants or contracts (Kerlin, 2006).

\section{Enabling effects of government funding}

In a well-functioning democracy the government should encourage NGO advocacy. NGOs create a more informed citizenry and give voice to marginalized populations (Reimann, 2006; Beyers and Kerremans, 2007; Greenwood, 2007; Mahoney, 2008; Mahoney and Beckstrand, 2011: 1343). Thus, NGOs contribute to more informed public policy (Wilson, 1983; Saurugger, 2011). The positive relationship should be strong within the EU, given its mandate to develop civil society (Streeck and Schmitter, 1991; Steffek et al., 2008; Mahoney and Beckstrand, 2011; Sanchez Salgado, 2014), perceived democratic deficit (Halpin, 2006; Beyers and Kerremans, 2007; Greenwood, 2007; Kohler-Koch and Finke, 2007; Klüver and Saurugger, 2013), and lack of institutional capacity for policy-making and implementation (Streeck and Schmitter, 1991; Dür, 2008; Greenwood, 2010).

Government funding can increase NGO access to government officials by establishing credibility (Crawford and Sobel, 1982; Baumgartner and Leech, 1998; Pallas and Uhlin, 2014). NGOs can use government funding to build capacity for information collection and expertise, while signaling government interest on a given policy issue (Wilson, 1983; Leech, 2006; Ruggiano and Taliafero, 2012). Government-funded NGOs are more likely to use insider lobbying to avoid jeopardizing relationships with government officials (Mosley, 2011; Kearns et al., 2014; Moulton and Eckerd, 2012; Lecy and Van Slyke, 2013). NGOs' relationships with government agencies can create a 'paradigm of partnership' fostering advocacy (Ullman, 1999; Salamon, 2002; Campbell, 2003). Government agencies and NGOs interested in maintaining (increasing) funding for a program may lobby together. NGOs have incentives to lobby to improve conditions for their beneficiaries and their own funding (Smith and Lipsky, 1993; Chaves et al., 2004). 
Government funding is argued to increase NGO lobbying for normative and strategic reasons. Civil society participation is necessary to represent and give voice to the marginalized populations (Boris and Mosher-Williams, 1998; Berry, 2005; Halpin, 2006; Greenwood, 2007). NGOs are especially important supranationally. '[S] upranational interest group formation was expected to serve, in an important and indispensable sense, as a substitute for popular identification with the emerging new political community above and beyond the nation-state' (Streeck and Schmitter, 1991: 133). Mahoney and Beckstrand (2011) find that the EU funds NGOs advocating for the development of EU identity, democracy, and civic engagement preferentially.

\section{National vs. European financing}

We expect to find different effects of government financing at the national and supranational (European) levels. 'There is some general acceptance of the notion that supra-national forms of government (as compared to nation states) tend to rely more heavily on groups ... the lack of resources, autonomous capacity and direct accountability to citizens arguably makes them more reliant on groups than national governing institutions' (Greenwood and Halpin, 2007: 195). We believe these differences occur for three reasons: existing state-society relations, differential need for NGO expertise and information, and different ideas of NGO legitimacy. At the national level, NGOs are threatening to longstanding state-society relations and established peak associations (Bloodgood et al., 2014). The EU seeks sources of interest intermediation, given its relative newness and distance from the people (Streeck and Schmitter, 1991). The EU has created consultation mechanisms and grants to generate political and economic opportunities for Europeanized interest groups (Beyers and Kerremans, 2007; Greenwood, 2007; Sanchez Salgado, 2014).

Second, democratic legitimacy problems are greater at the EU level. Popular perception of a democratic deficit has led to demands for the rapid development of NGOs at the supranational level (Greenwood and Halpin, 2007; Steffek et al., 2008). NGOs acting as interest groups are less accepted at the national level, as many countries explicitly constrain charities from political activities (Berry, 2003). Political parties provide interest representation at the national level; a political void at the supranational level creates opportunities for NGOs to represent otherwise excluded interests (Beyers and Kerremans, 2007; Greenwood, 2007; Kohler-Koch and Finke, 2007; Mahoney and Beckstrand, 2011; Saurugger, 2011).

Third, the need for NGO expertise is greater in the EU, given complex, transnational challenges. European bureaucrats favor NGOs as experts to address complex interdependence without contagion from national interests (Streeck and Schmitter, 1991; Sanchez Salgado, 2014). The recent adoption of governance responsibilities, relative newness of the bureaucracies, and interest compatibility 
between bureaucrats and NGOs (similar focus on broad problem solving vs. narrow national interests) increase the affinity between the EU and NGOs (Streeck and Schmitter, 1991; Dür, 2008; Greenwood, 2010). Cynical scholars might argue that NGOs are given greater influence in the EU, where less important decisions are made, and relegated to implementation roles in national decision-making.

\section{Previous findings}

Empirically, results are mixed. In US surveys, Salamon (2002), Bass et al. (2007), Mosley (2011), Moulton and Eckerd (2012), and Smith and Pekkanen (2012) find a statistically significant positive relationship between government funding and NGO advocacy. Ullman (1999), Chaves et al. (2004), Greenwood (2007), Císar and Vráblíková (2013), Sanchez Salgado (2014), and Neumayr et al. (2015) find that, in European countries, national government funding does not restrict or reduce political activity, and EU funding has empowering effects on NGOs. Other scholars find that government funding dampens political activism. Child and Gronbjerg (2007) and Anheier et al. (1997) find that NGOs receiving 50\% or more of their resources from the government participated significantly less in advocacy or felt at risk of goal distortion. Schmid et al. (2008) find a significant negative relationship between government funding and political activity among NGOs, even below 50\%.

We believe three factors explain these contradictions. First, there is no single operationalization of advocacy. Some focus on the presence of advocacy, by asking NGOs if they engage in lobbying (e.g. Chaves et al., 2004; Leech, 2006; Ruggiano and Taliaferro, 2012). Government funding could be associated with a decrease in the extent of NGO advocacy without stopping advocacy completely. In studies of the extent of NGO advocacy, dependent variables vary from amount of expenditure to event counts for specific activities (e.g. Boris and Mosher-Williams, 1998; Berry, 2005). Studying expenditure may underestimate low-cost activities, while self-reported acts of advocacy are difficult to compare. Second, the NGO sector is hard to define. Different databases use different criteria and thus contain different organizations (Boris and Mosher-Williams, 1998; Berry, 2005; Berkhout and Lowey, 2008; Greenwood and Dreger, 2013).

Third, most studies focus on regions within the United States (for non-US perspectives, see Anheier et al., 1997; Beyers and Kerremans, 2007; Onyx et al., 2008; Schmid et al., 2008; Císar and Vráblíková, 2013; Sanchez Salgado, 2014; Neumayr et al., 2015). Differences among NGO populations could explain some variation in the results. Because of its US bias, past research has not investigated thoroughly the effects of national vs. supranational funding on NGO political behavior. Using EU data, we examine the effects of government funding from national and supranational sources across multiple countries. We reproduce the contradictions seen in past research through the use of different statistical estimation techniques. 


\section{Hypotheses}

We argue that there is a strong negative relationship between national government financing and NGO lobbying expenditure, but the relationship is weak for supranational (EU) funding. We test five hypotheses to explore contradictory findings in the literature. We also examine two mechanisms to account for the effects of government financing on NGO lobbying expenditure: government threat vs. NGO self-selection.

HYPOTHESIS 1: NGOs that receive any public financing are less likely to lobby than NGOs that do not.

HYPOTHESIS 2: NGOs that receive most of their funding from government sources spend less on lobbying than NGOs that do not.

HYPOTHESIS 3: NGOs that receive more public financing as a share of budget spend less on lobbying as a share of budget.

HYPOTHESIS 4: Public funding from national governments has a dampening effect on NGO lobbying expenditure; public funding from the EU does not have the same strength or direction effect.

HYPOTHESIS 5: The sector (issue) and national context (restrictiveness of national regulations) have a smaller effect on NGO lobbying expenditure than funding source.

\section{Research design}

We examine these hypotheses using the European Union's Transparency Register (EUTR). ${ }^{6}$ This source provides more complete and consistent data, particularly on funding and lobbying, than other sources, including the UIA's Yearbook of International Organizations and the United Nation's (UN) iCSO data set. ${ }^{7}$ As of 2008, all organizations wishing to engage in political activities in the EU are expected to register (L191/30). While registration is voluntary, NGOs and other interest groups must register to gain accreditation and access to the EU Parliament. Information must be updated annually or the organization is removed from the Register.

We draw from section III, 'nongovernmental organizations, platforms and networks, and similar', defined as 'not-for-profit organizations (with or without legal status), independent from public authorities, political parties or commercial organizations' (Annex 1, L191/33-34). Organizations self-select their category, but are instructed to 'select the section or subsection that most accurately reflects the

\footnotetext{
6 http://europa.eu/transparency-register/

${ }^{7}$ http://esango.un.org/civilsociety/login.do
} 
nature of their organization and work' (EUTR, 2012: 5). There are limited strategic incentives to choose NGO (section III) vs. another category (section I, professional consultancies/law firms, or section II, in-house lobbyists, professional/trade associations). Organizations report similar information, with this exception: consultants and law firms report turnover from activities within the scope of the register, in-house lobbyists and trade/professional associations report estimated costs of activities, and NGOs report overall budget (Annex 1, L191/36). Registered organizations cannot use the EUTR as a 'publicity tool' or means of self-promotion. The Joint Transparency Register Secretariat has the authority to contest and remove organizations, including those with profiles found to contain 'purely gratuitous statements that cannot be backed up with facts or results' (EUTR, 2012: 8).

We use reported lobbying expenditure as a measure of NGO advocacy and our proxy for political activity. Reported lobbying expenditure is an imperfect indicator of political activity, as discussed earlier, but is the best measure available for quantitative cross-national research. The inclusion of lobbying expenditure in the Register suggests its importance as an indicator for the EU itself. Because lobbying expenditure is systematically assessed, it is likely to play a role in future EU policy-making on non-state advocacy.

NGOs are expected to report the estimated cost of 'all activities ... carried out with the objective of directly or indirectly influencing the formation or implementation of policy and the decision-making processes of the EU institutions, irrespective of the channel or medium of communication used' (L191/30/IV/8). Information is self-reported, but 'by registering, the organization and individuals concerned ... guarantee that the information provided for inclusion in the register is correct' (L191/30 v.17). Lobbying expenditure includes the costs of contacting government officials and their staffs, preparing and circulating promotional material and letters, participating in formal and open consultations, and organizing meetings (including social events and workshops) with government officials (L191/ 29/22.7.2011; L277/11/19.9.2014). Lobbying figures are the organization's estimate of the costs of direct and indirect interest representation to EU institutions in a year, including staffing, in-house operational and office expenditure, representation costs, hiring lobbying firms, and membership fees for joining networks and coalitions, rounded to the nearest 25,000 euros (from 0 to $>10$ million euros) (JTRS, 2015: 13).

Reported lobbying expenditure measures both cooperative advocacy via coalition building and networking within government structures (as expected by the European interest group literature) and adversarial approaches and indirect lobbying via media campaigns (as expected by the American interest group literature). ${ }^{8}$ We expect this to

\footnotetext{
${ }^{8}$ Advocacy activity for self-promotion, including to secure funding (Smith and Lipsky, 1993; Ullman, 1999; Mosley, 2012), would not be counted unless the activity was also directed at a specific policy or decision-making process. This is supported empirically by the lack of endogeneity in our results (see Seccombe, 2014).
} 
be understated, nonetheless. NGOs are prohibited from partisan politics in some countries and many NGOs do not view political activities like education and awarenessraising as lobbying (Ruggiano and Taliaferro, 2012). Zero declarations for lobbying must be justified, however, and the Secretariat contacts organizations when this is missing. A failure to explain this results in being dropped from the register (EUTR, 2012: 4). We control for the headquarters country of each NGO to account for national restrictions like prohibitions on lobbying by charities.

We choose to use the Transparency Register, rather than the UIA or the UN, because its reporting requirements produce more complete and consistent data. The UIA Yearbook of International Organizations is the 'gold standard' for data on NGOs in most academic research. The UIA provides self-reported data on some of the same variables as the EUTR across a larger set of organizations operating in more countries. Financial data are largely missing, however, as NGOs can choose not to report it and still appear in the Yearbook, and the UIA does not ask NGOs about lobbying activities. The UIA also lacks the EUTR's authority to check information or remove non-compliant organizations.

The UN's iCOS data set $^{9}$ makes available information on an expanding set of organizations. The NGO Branch of the UN Department of Economic and Social Affairs, like the EUTR Joint Secretariat, has the authority to compel information, particularly from NGOs with consultative status. This data set does not make financial information on organizations public, however. Furthermore, the Transparency Register includes a diversity of NGOs interested in engaging with the EU at different levels of formality and commitment, while iCOS only contains complete data for NGOs granted UN consultative status. Governments can limit the political capacity of NGOs by denying consultative status and thus iCOS may over-represent less politically active organizations. While national data from tax authorities or charity registers provide the most complete data on the greatest range of NGOs with the most coercive authority to prevent false reporting, these data are only available for a few countries and reporting categories are not easily compared. ${ }^{10}$

The EUTR provides the most complete and accurate data on NGO financing and political expenditures. It replaces the CONECCS (Consultation, the European Commission and Civil Society) database (Berkhout and Lowery, 2008; Mahoney and Beckstrand, 2011), which was discontinued in 2008. Greenwood and Dreger (2013) estimate that EUTR contains about $60 \%$ of NGOs interested in the EU and argue that the EUTR, while flawed, is better than competitors. ${ }^{11}$ As the stakes of

\footnotetext{
9 http://esango.un.org/civilsociety/login.do

${ }^{10}$ National data are available for England and Wales, Scotland, Spain, the Netherlands, Norway, Belgium, the United States, Canada, New Zealand, and Australia.

${ }^{11}$ Greenwood and Dreger (2013) find 15\% of organizations registered as NGOs should be categorized as trade/business/professional associations and some lobbying expenditures are suspicious or mistaken (ALTER-EU, 2012; Greenwood and Dreger, 2013).
} 
misreporting are high and the financial data must be reported in a specific way and tally correctly, the likelihood of honesty is increased. The Joint Secretariat has prepared updated Guidelines to assist organizations in data reporting.

While our sample is skewed toward advocacy NGOs from Europe operating transnationally, descriptive statistics show substantial diversity. In total, 356 NGOs have no reported lobbying expenditures, 472 have no reported government funding, and 154 have neither [see Table A1 (Appendix)]. Almost two-thirds are headquartered in Western Europe, but they are evenly split between national NGOs and international NGOs (operating in more than three countries) (Table A2). The range of organizations in the EUTR, with diverse funding sources, political expenditures, home countries, geographic focus, and issue areas, thus allows us to test our depoliticization hypotheses.

We estimate multiple statistical models. Lobbying expenditure and public funding are treated as dichotomous and continuous variables to test if whether NGOs receive government funding or the amount of funding effects whether NGOs engage in lobbying and the extent of their lobbying expenditure. Ordinary least squares and binomial logistic regression models are fitted, depending upon the dependent variable. Logs of financial measures adjust for the skewed distribution of NGO financing. We also estimate a fractional logistic model (Buis, 2006; Baum, 2008 ) given the number of ' 0 's and ' 1 's that occur in our measures of government financing and lobbying expenditure as a share of NGO budget. We use the ' $\mathrm{glm}$ ' function in STATA with the assumption of a binomial distribution and a logistic link function, as recommended by Baum (2008) and Buis (2006). To test whether governments fund some organizations but not others (or whether NGOs choose financial sources over others), we treat the ' 0 's and ' 1 's as generated by the same processes as the rest of the data (i.e. not exogenous or errors). We compare the results of the fractional logit model with a zero-one inflated beta model and find that the fractional logit model fits better (Table A6) (Table 1).

Table 1. Descriptive statistics

\begin{tabular}{lcccr}
\hline \hline Variables & $N$ & Mean & Minimum & Maximum \\
\hline Lobbying expenditure & 1105 & 63,751 & 0 & $1,000,000$ \\
Public financing & 1105 & $2,048,639$ & 0 & $6.44 \mathrm{e}+08$ \\
National financing & 1105 & 956,997 & 0 & $4.26 \mathrm{e}+08$ \\
European financing & 1105 & 316,650 & 0 & $1.20 \mathrm{e}+08$ \\
NGO budget & 1105 & $6,260,685$ & 0 & $8.07 \mathrm{e}+08$ \\
NGO regulatory index & 934 & 1.85 & 0 & 5.5 \\
Number of countries of operation & 1105 & 9 & 0 & 50 \\
Humanitarian aid & 1105 & 0.25 & 0 & 1 \\
Foreign affairs & 1105 & 0.18 & 0 & 1 \\
Energy & 1105 & 0.26 & 0 & 1 \\
Equal opportunity & 1105 & 0.32 & 0 & 1 \\
\hline \hline
\end{tabular}

$\mathrm{NGO}=$ non-governmental organization. 
NGO budget, a measure of NGO regulations in the NGO's home country, and the number of countries in which the NGO has offices or affiliates control for size and legal, institutional, and cultural inclinations toward government funding. States' funding of civil society and NGOs' share of government vs. private funding vary cross-nationally (Salamon et al., 2004: 301). National regulations may constrain, or incentivize, government funding of NGOs according to national political preferences or traditions, and may prohibit lobbying expenditure by NGOs. The NGO regulatory index (Bloodgood et al., 2014) measures the extent to which a country enables or restricts NGOs through its regulations. Higher values on the index (which ranges between -7 and 8) signify more enabling national regulations.

All models include dichotomous variables for the following self-reported issue interests: humanitarian affairs, energy, or equal opportunity. International development organizations are argued to receive more government funding, given their large operating budgets and preference for service over advocacy. These organizations may be more willing to self-censor as government funding may be the only source large enough to sustain them (Fowler, 1992; Stroup, 2012). Humanitarian affairs, rather than development, is used as a proxy because of the risk that 'development' is seen as 'fundraising' rather than issue focus. While $25 \%$ of the NGOs in the data set claim to work on humanitarian aid, 39\% claim development.

Environmental and human rights organizations are argued to privilege their autonomy and independence, restricting themselves to private funding (Wells, 2001). Energy is used for environment, rather than food security or fishing, as it reflects a diversity of environmental NGOs. While $26 \%$ of NGOs work on energy, only $16.5 \%$ work on fish and $19 \%$ on food security. Equal opportunity is the closest proxy for human rights. In robustness checks of the issue measures, alternative specifications do not change the magnitude or statistical significance of the relationship between lobbying expenditure and public financing.

Scholars observe differences in size and funding needs between national and international non-governmental organizations (INGOs). INGOs are larger and need more funding for basic maintenance, but have access to more varied funding sources. INGOs thus might have different funding profiles than national organizations (Reimann, 2006). Their access to multiple national contexts might influence their lobbying expenditure; access to multiple policy arenas and government funders may help INGOs avoid government pressure to reduce advocacy. We include a count of the number of countries of operation. ${ }^{12}$

\section{Government funding and NGO lobbying}

To explore government funding and NGO political activity, proxied by reported lobbying expenditure, we focus on three aspects - the extent to which public

\footnotetext{
${ }^{12}$ We include interest in foreign affairs as a proxy for international focus, even if NGOs are not organized transnationally. This is statistically insignificant in most models.
} 
funding affects lobbying expenditure, the effects of different sources of public financing, and the variations in these effects in different NGO populations.

\section{Public financing}

To assess past contradictory results, we model the relationship between government financing and NGOs' reported lobbying expenditure in three different ways (Table 2). First, we test for a black-and-white relationship between government financing and NGO lobbying using dichotomous variables for the presence of government funding and lobbying expenditure. We hypothesize that NGOs receiving any government money are less likely to engage in lobbying. We estimate a logistic regression with variables coded 1 if the NGO receives any government financing ( 0 if they do not) and 1 if the NGO spends any money on lobbying (0 if they do not).

The results of the logistic regression are mixed. The coefficient on the public funding dummy is statistically significant and negative (Table 2, column 1), but marginal effects are small. Government-funded NGOs are $6.8 \%$ less likely to lobby. If we separate national and European funding, the coefficients on the two dichotomous variables are not statistically significant. Table A5 (Appendix) shows all models. Accepting some government financing is not sufficient to prevent NGOs from lobbying. Of the 781 NGOs that receive government financing, 66.7\% (or 521) report spending some money on lobbying. The pseudo $R^{2}$ for this regression is low, accounting for only $2.7 \%$ of the variation.

Second, we test the relationship between public financing and lobbying expenditure using continuous variables. Table 2 , column 2 provides the results of an

Table 2. Public financing and NGO lobbying

\begin{tabular}{lccc}
\hline \hline & $\begin{array}{c}\text { Lobbying dummy } \\
\text { (marginal fixed effects) }\end{array}$ & $\begin{array}{c}\text { Lobbying expenditure } \\
\text { (euros logged) }\end{array}$ & $\begin{array}{c}\text { Lobbying expenditure } \\
\text { (euros) }\end{array}$ \\
\hline Public financing D & $-0.0678(0.033) * *$ & $-0.0929(0.031) * * *$ & $8985(11,052)$ \\
Log public financing & & & $-19,948(12,628)$ \\
$50 \%$ threshold & $0.0215(0.005) * * *$ & $0.4708(0.048) * * *$ & $10,672(1292) * *$ \\
NGO budget $(\log )$ & $-0.0115(0.010)$ & $-0.2315(0.112) * *$ & $-7294(2549) * *$ \\
Regulatory index & $0.0015(0.001)$ & $0.0273(0.014) * *$ & $1594(367) * * *$ \\
Number of countries & $-0.0216(0.042)$ & $-0.1129(0.441)$ & $-3218(9058)$ \\
Humanitarian aid & $0.0600(0.045)$ & $0.5106(0.473)$ & $21,474(12,068) *$ \\
Foreign affairs & $0.0453(0.034)$ & $0.4380(0.363)$ & $14,968(9667)$ \\
Energy & $0.0286(0.035)$ & $0.2400(0.376)$ & $5634(9010)$ \\
Equal opportunity & 0.03 & 0.09 & 0.12 \\
$R^{2}$ & 934 & 934 & 934 \\
$N$ & 9
\end{tabular}

$\mathrm{NGO}=$ non-governmental organization.

Standard errors in parentheses.

$* P<0.10 ; * P<0.05 ; * * P<0.01$. 
OLS regression analysis of the relationship between the euro value of the public funding NGOs receive (logged) and their expenditure on lobbying (logged). ${ }^{13}$ We find public financing has a statistically significant negative effect on lobbying expenditure. For each $10 \%$ increase in public financing, NGOs spend $0.9 \%$ less on lobbying. The size of the NGO budget, the national regulatory climate (NGO Regulation Index), and the number of countries of operation have large, statistically significant effects on lobbying behavior. For each $10 \%$ increase in its budget, an NGO spends $4.7 \%$ more on lobbying. Each additional country of operation increases its lobbying expenditure by $2.7 \%$. As national regulations become more permissive, however, lobbying expenditure decreases (about 23\% for each index point). The fit of this model is better than the dichotomous variable model $\left(R^{2}=0.09\right)$.

Third, we examine a threshold effect; previous studies argue when NGOs receive a majority of funding from public sources they become dependent upon, and more responsive to, government (Anheier et al., 1997; Child and Gronbjerg, 2007). 'Critical' resource dependence has strong effects as NGOs cannot easily adapt (Beyers and Kerremans, 2007: 464). Císar and Vráblíková (2013: 154) find that EU financing empowers NGO political activity, but only when the NGO receives more than $40 \%$ of their funding from the EU. Table 2, column 3 shows the results of regression analysis of lobbying expenditure, public funding in euros, and 'dependence', coded 1 if an NGO is more than $50 \%$ government funded. While the signs on the coefficients are consistent with our expectation that NGOs that receive some government funding behave differently from NGOs that receive the majority of their funding from government sources (Hypothesis 2), they are not statistically significant and the fit of the model is weak $\left(R^{2}=0.12\right)$.

We conclude that different specifications of the relationship between government funding and NGO lobbying expenditure support different conclusions consistent with the existing literature. We find an overall negative relationship between public funding and NGO lobbying expenditure, as expected, but no support for a threshold effect. We also find that issue focus does not significantly affect NGO lobbying expenditure, but size of the budget and NGO location do matter in most models.

The distribution of public funding and reported lobbying expenditure among NGOs in the Transparency Register poses a challenge to our analysis, while supporting our intuition. Both variables are exponentially distributed and the graph of public financing against reported lobbying expenditure as a proportion of total budget is U-shaped. We conduct non-parametric tests for association with public financing and reported lobbying expenditure as a share of total budget grouped by deciles. We find a statistically significant, negative relationship between public financing and reported lobbying activity as a share of government spending. ${ }^{14}$

\footnotetext{
13 We use an adjusted log transformation of public financing and lobbying expenditures; zeros in the original variable are set to zero in the logged variable (Hyndman and Grunwald, 2000).

${ }^{14}$ Pearson's $\chi^{2}(100)=170, P=0.000$; Kendall $\tau_{b}=-0.1181, z=-4.724$; Goodman and Kruskal's $\gamma=-0.1474, z=-4.6063$.
} 
Table 3. Government financing and lobbying share

\begin{tabular}{lccc}
\hline \hline \multicolumn{4}{c}{ Marginal fixed effects, spending on lobbying as share of budget } \\
\hline Public funding as \% budget & $-0.0985(0.039)^{* *}$ & - & - \\
National funding as \% budget & - & $-0.1232(0.059) * * *$ & - \\
European funding as \% budget & - & - & $0.0423(0.062)$ \\
NGO budget (log) & $-0.0962(0.012) * * *$ & $-0.0968(0.012) * * *$ & $-0.1003(0.012) * * *$ \\
NGO regulatory index & $-0.0280(0.010)^{* * *}$ & $-0.0280(0.010)^{* * *}$ & $-0.0287(0.010) * * *$ \\
Number of countries & $0.0028(0.001)^{* *}$ & $0.0024(0.001) * *$ & $0.0030(0.001) * * *$ \\
Humanitarian aid & $-0.0622(0.038)^{*}$ & $-0.0545(0.038)$ & $-0.0585(0.037)$ \\
Foreign affairs & $0.0850(0.045) * *$ & $0.0865(0.044) * *$ & $0.0929(0.045) * *$ \\
Energy & $0.0888(0.03) * * *$ & $0.0901(0.03) * * *$ & $0.0939(0.03) * * *$ \\
Equal opportunity & $0.0400(0.031)$ & $0.0300(0.031)$ & $0.0238(0.031)$ \\
AIC & 0.9523 & 0.9537 & 0.9568 \\
BIC & -5490 & -5489 & -5486 \\
$N$ & 906 & 906 & 906 \\
\hline \hline
\end{tabular}

$\mathrm{NGO}=$ non-governmental organization; $\mathrm{AIC}=$ akaike information criterion; $\mathrm{BIC}=$ bayesian information criterion.

Standard errors in parentheses.

$* P<0.10 ; * P<0.05 ; * * P<0.01$.

We use a fractional logistic regression model to test whether NGOs that receive more public funding spend less money on lobbying as a share of budget. Table 3 shows the results of the models estimated for total public funding (column 1), national funding (column 2), and European funding (column 3).

We find, supporting our third hypothesis, that public funding has a sizeable, statistically significant, negative effect on NGO lobbying. For a $10 \%$ increase in the public funding share of budget, NGOs reduce reported lobbying expenditures as a share of budget by about $1 \%(B=-0.0985 ; \mathrm{SE}=0.039)$. We predict the difference in lobbying expenditure between NGOs with no government funding and NGOs with only government funding will be $9.7 \%$ of their budget, all else equal. The predicted lobbying expenditure as a share of budget drops from 36.4 to $26.7 \%$ when government funding as a share of budget shifts from 0 to $100 \% .^{15}$

\section{National vs. European funding}

Not only should public funding affect NGOs' lobbying, but the source of public funding should change the relationship. We hypothesize that national funding will

15 If lobbying expenditure increases public funding, creating endogeneity, we would expect a positive relationship. Instead we find a weak negative correlation between the share of lobbying in the budget and the total budget $(r=-0.0952, P=0.000)$. In a regression of lobby expenditure against public financing, the coefficient on lobbying expenditure is not statistically significant $(b=-1.888 ; t=-0.52)$. We conclude endogeneity is not a problem. 
have a dampening effect on NGO lobbying expenditure compared with European funding. National governments have strategic and normative reasons to limit NGOs' political influence, while supranational institutions benefit from NGOs' democratic legitimacy and expertise. We find support for this hypothesis. The relationship between share of public funding and share of lobbying expenditure becomes more negative (but equally statistically significant) when focusing strictly on national funding. EU funding as a share of NGO budget has no statistically significant effect on reported lobbying expenditure.

As Table 3 shows, a 10\% increase in public funding (share of budget) results in a $1 \%$ decrease in reported lobbying expenditure (share of budget), while a similar $10 \%$ increase in funding from national governments results in a $1.2 \%$ decrease in reported lobbying expenditure. The predicted lobbying budget of organizations that received no national funding, compared with those that received all of their funding from national governments, all else equal, changes from 35 to $23.3 \%$, a drop of $11.7 \%$. The coefficient on European funding as a percentage of total budget, on the other hand, is positive $(0.0423)$ and not statistically significant. Changes in European funding as a share of budget do not effect NGO lobbying expenditure. When national and European funding are in the same model, the results are the same (Table 3, column 4). ${ }^{16}$

We thus find support for our fourth hypothesis; funding from different levels of government has differential effects on reported lobbying expenditure. National funding reduces NGOs' reported lobbying expenditure, consistent with resource dependency arguments and American views of interest group politics (Chaves et al., 2004; Berry, 2005; Leech, 2006; Suarez, 2011). European funding does not reduce NGO-reported lobbying expenditure, consistent with European scholarship on the mutually beneficial relationship between interest groups and the EU (Kohler-Koch and Finke, 2007; Beyers et al., 2008; Mahoney and Beckstrand, 2011; Sanchez Salgado, 2014).

\section{Sector and home country}

We examine the relative effects of sector and national origin (compared with funding composition) on NGO-reported lobbying expenditure. We proposed that NGOs in sectors requiring large budgets, such as international development (humanitarian affairs), may choose to lobby less. NGOs in the environment and human rights sectors (energy and equal opportunity) may forego government funding to maintain their autonomy. We hypothesize that this 'self-selection' mechanism has a smaller effect on NGO lobbying expenditure than public financing, which our findings confirm.

\footnotetext{
${ }^{16}$ Robustness checks, Table A7, demonstrate that this is not the result of an advocacy focus (proxied by a Belgium office or members) or a focus on the EU (proxied by an interest in enlargement, trans-EU networks, or the internal market). The results are similar to those in the full sample - public funding and national funding have negative coefficients (significant only for Belgium), while EU funding is not significant. The number of observations falls dramatically.
} 
In Table 3, energy, our proxy for environment, is statistically significant, but its substantive effect is smaller than public funding. Environmental NGOs spend a slightly larger share of their budgets $(\sim 0.9 \%)$ on lobbying activities, while humanitarian aid organizations spend slightly less (the coefficient is not statistically significant in most models). In Table 2, issue area is not statistically significant. The source of NGO funding has a larger effect on lobbying expenditure than sector, providing support for perceived government threat over NGO self-selection to explain differences in reported lobbying expenditure.

The number of countries where an NGO operates affects lobbying expenditure as a share of budget. While being an international NGO does not affect willingness to lobby (Table 2, column 1), it affects the amount spent on lobbying (Table 2, columns 2-3; Table 3). The coefficient on the number of countries of operation is positive and statistically significant in Tables 2 and 3. NGOs operating internationally tend to spend more on lobbying, possibly because of their size and visibility.

The regulatory environment of an NGO's home country also has statistically significant effects on lobbying expenditures. NGOs from permissive home countries, with more legal, political, and/or economic latitude, spend statistically significantly less on lobbying. The coefficient on the NGO regulatory index variable is statistically significant and negative across Tables 2 and 3. A one-point increase in the permissiveness of national regulations decreases lobbying expenditure by $2.8 \%$ of the NGO's total budget, all else equal. NGOs in the most permissive countries spend, on average, $15.4 \%$ less of their budget on lobbying than NGOs in the most restrictive countries.

There are two possible explanations. NGOs from more permissive countries may be less willing to antagonize a government that could impose more restrictive regulations. Alternatively, more permissive regulation may signal a good working relationship between government and NGOs. If a government partner shares the same goals, NGOs can reduce lobbying and work within official channels. This suggests that NGOs can ally with government, as expected in the European model of interest group politics (Streeck and Schmitter, 1991; Halpin, 2006; Kohler-Koch, 2007; Steffek and Hahn, 2010). The negative relationship between national funding and lobbying expenditure, however, provides support for the adversarial model of interest group politics underpinning our argument.

We conclude that government financing of NGOs, particularly national funding, has a stronger depoliticizing effect on NGOs' lobbying expenditure than sector. National regulations and number of countries of operation likely affect resource dependence and thus the impact of government financing on reported lobbying expenditure. NGOs active in more countries and NGOs from more restrictive regulatory contexts have greater reported lobbying expenditure.

\section{Conclusions}

We argue that the question should not be 'does government financing affect NGO political activity (reported lobbying expenditure)?', but 'how does funding from 
different government sources affect NGO political activity?'. We find that the greater the proportion of an NGO's budget that comes from government sources, the less of its budget it reports spending on lobbying. This effect is stronger when funding comes from national governments, while EU funding does not have a dampening effect. We posit this negative relationship can best be explained by governments' ability to threaten to limit funding (or NGOs' perception of a threat) such that they become less outspoken on policy.

Our results are consistent with past qualitative research. Edwards and Hulme write ' $t]$ he increasing numbers of NGOs in many countries, a growth in the size of individual NGOs, an increasing concentration on service provision, and rising reliance on official funding all seem to be related' (1996: 3). Ian Smillie concludes '[i]nstitutional funding represents a step forward in the ability of government to manage and control Canadian NGOs and a step backward from the concept of NGOs as independent expressions of civil society' (1996: 192). Andrew Natsios, as chief administrator of United States Agency for International Development (USAID), told NGOs in Iraq in 2003 that they are 'arms of the U.S. government' and threatened to replace those who did not support US foreign policy (quoted in Nelson and Dorsey, 2008: 102). Similarly, Australia in 2014 explicitly tied government funding and NGO political advocacy with clauses in grants that prohibited the use of government money for advocacy (Seccombe, 2014). NGOs in the United Kingdom have also expressed concern. An Independence Panel report cited by Jude Howell in The Guardian states that 'as many organizations fear for their survival, self-censorship is becoming a significant problem'. ${ }^{17}$ Furthermore, participants in the Bass et al. (2007) SNAP (Strengthening Nonprofit Advocacy Project) focus groups said they avoided advocacy for fear of antagonizing government.

We also test the argument that depoliticization may be due to self-selection by NGOs, as outspoken NGOs choose alternative funding to maintain independence and legitimacy. We find that issue has less effect on lobbying expenditure than funding composition. We thus believe that government funding has a greater role to play in NGO depoliticization than self-selection. Because the relationship between funding source and reported lobbying expenditure does not vary by sector, NGOs do not seem to reduce their lobbying based on their issue interests. The relationship between government funding and lobbying expenditure thus seems driven by (perceived) government actions. The strength of this conclusion is moderated by the nature of the data, which lacks the full population of NGOs in the EU, and relies on voluntary self-reporting, we believe that the results are likely understated. The missing NGOs are more likely to be less political (hence non-participation in the EUTR) than the organizations registered.

Our research has theoretical and policy implications. We demonstrate that the relationship between government financing and NGO lobbying expenditure

\footnotetext{
17 http:/www.theguardian.com/global-development-professionals-network/2013/mar/26/worldsocial-forum-ngos-fit-for-purpose
} 
depends on model specification, providing an explanation for past contradictory findings. We can account for no relationship between lobbying and government financing, a strongly negative, and a weakly positive relationship, depending on raw or relative amounts of financing and lobbying and national or supranational funding. We conclude, however, that national government funding as a share of budget has a strong and statistically significant negative effect on NGO lobbying expenditure that cannot be attributed to NGOs' sectoral focus alone.

Fears about NGO resource dependence may be even greater than previously argued (Froelich, 1999; Beyers and Kerremans, 2007; Suarez, 2011). Governments may not be acting in a politically benign fashion when they fund NGOs. The dampening effect of government funding on NGO lobbying may be political manipulation by governments. Reductions in lobbying expenditure could be attributed to NGO cooperation with governments, as expected by the European model of interest group politics (Wilson, 1983; Greenwood, 2007; Beyers et al., 2008; Saurugger, 2011). But stronger support for the government threat than the NGO self-selection mechanism for depoliticization raises questions. Reduced lobbying expenditure may be due to shifts from external lobbying to collaborative networking with government officials (Bass et al., 2014), but NGO reporting to the EUTR includes costs for coalition building. Lobbying is a costly signal of credibility and spending less money could result in reduced policy influence. Future research should examine whether NGOs reduce their lobbying because they feel less need or less ability to lobby.

We integrate several fields of NGO research - resource dependence and accountability from sociology and management with NGO advocacy from political science (Cowles, 2003). International Relations (IR) focuses on the activities of NGOs against states, often new norms to constrain state behavior (e.g. Reimann, 2006; Stroup, 2012; Pallas and Uhlin, 2014). Sociology and management focus on the financial pressures NGOs face for survival and accountability (e.g. Chaves et al., 2004; Suarez, 2011; Verburggen et al., 2011; Kearns et al., 2014; Mitchell, 2012). IR has generally ignored the public funding of NGOs in its focus on their non-state attributes. We demonstrate that government funding is an important factor in explaining the frequency and location of NGO lobbying, and thus the ability of NGOs to influence national and global politics.

This research has implications for EU and UN efforts to foster civil society and popular engagement. To the extent that public funding dampens NGO advocacy, it may not be possible to artificially grow civil society with government funding. We find that EU funding has little dampening effect compared with national funding, but external funding may create concerns about international interference in national governance (Mendelson and Glenn, 2002). Political NGOs may need to be privately funded to serve a full range of political functions. Just as the EU interest group literature raises concerns about the democratic legitimacy of NGOs and their ability to serve as popular representatives if their structures are not democratic and their membership not grassroots (Warleigh, 2001; Halpin, 2006; Greenwood, 
2007; Greenwood and Halpin, 2007; Kohler-Koch and Finke, 2007; Steffek and Hahn, 2010; Saurugger, 2011), NGO financing may also have significant effects on NGO's role as effective advocates and representatives.

\section{Acknowledgments}

Paper presented at the International Studies Association Annual Conference, San Francisco, CA, 4-6 April 2013 and the Association for Research on Nonprofit Organizations and Voluntary Associations Annual Conference, Indianapolis, IN, 15-17 November 2012. The authors thank Jens Steffek for his excellent comments.

\section{Supplementary material}

To view Supplementary material for this article, please visit http://dx.doi.org/ doi:10.1017/S1755773915000430

\section{References}

ALTER-EU (2012), 'Dodgy data'. Retrieved 13 October 2014 from http://www.alter-eu.org/documents/ 2012/06/dodgy-data

Anheier, H., K. Toepler and S. Sokolowski (1997), 'The implications of government funding of non-profit organizations: three propositions', International Journal of Public Sector Management 10(3): 190-213.

Austen-Smith, D. (1994), 'Strategic transmission of costly information', Econometrica 62(4): 955-963.

Bass, G., A. Abrahamson and E. Dewey (2014), 'Effective advocacy', in R. Pekkanen, S. Smith and Y. Tsujinaka (eds), Advocacy and Nonprofits, Baltimore, MD: Johns Hopkins University Press, pp. 254-293.

Bass, G., D. Arons, K. Guinane and M. Carter (2007), Seen But Not Heard, Washington, DC: The Aspen Institute.

Baum, C. (2008), 'Stata Tip 63: modeling proportions', The Stata Journal 8(2): 299-303.

Baumgartner, F. and B. Leech (1998), Basic Interests, Princeton, NJ: Princeton University Press.

Berkhout, J. and D. Lowey (2008), 'Counting organized interests in the European Union', Journal of European Public Policy 15(4): 489-513.

Berry, J. M. (2005), 'Nonprofits and civic engagement', Public Administration Review 65(5): 568-578.

Berry, J. and D. Arons (2003), A Voice for Nonprofits, Washington, DC: Brookings Institute Press.

Bexell, M., J. Tallberg and A. Uhlin (2010), 'Democracy in global governance: the promise and pitfalls of transnational actors', Global Governance 16(1): 81-101.

Beyers, J. and B. Kerremans (2007), 'Critical resource dependencies and the Europeanization of domestic interest groups', Journal of European Public Policy 14(3): 460-481.

Beyers, J., R. Eising and W. Maloney (2008), 'Researching interest group politics in Europe and elsewhere', West European Politics 31(6): 1103-1128.

Bloodgood, E., J. Tremblay-Boire and A. Prakash (2014), 'National styles of NGO regulation', Nonprofit and Voluntary Sector Quarterly 43(4): 716-736.

Boris, E. and R. Mosher-Williams (1998), 'Nonprofit advocacy organizations', Nonprofit and Voluntary Sector Quarterly 27(4): 488-506.

Brown, D., A. Ebrahim and S. Batiwala (2012), 'Governing international advocacy NGOs', World Development 40(6): 1098-1108. 
Buis, M. (2006), 'Modeling for response variables that are proportions', UK Stata Users' Group Meetings. Retrieved 13 March 2013 from http://repec.org/usug2006/Buis_proportions.pdf

Chaves, M., L. Stephens and J. Galaskiewicz (2004), 'Does government funding suppress nonprofits' political activity?', American Sociological Review 69(2): 292-316.

Child, C. and K. Gronbjerg (2007), 'Nonprofit advocacy organizations', Social Science Quarterly 88(1): 259-281.

Císar, O. and K. Vráblíková (2013), 'Transnational activism of social movement organizations', European Union Politics 14(1): 140-160.

Coen, D. and J. Richardson (2009), 'Learning to lobby the European Union', in D. Coen and J. Richardson (eds), Lobbying the European Union, Oxford: Oxford University Press, pp. 3-15.

Commission of the European Communities. (2001), 'European governance'. COM, p. 428. Retrieved 25 July from http://ec.europa.eu/governance/white_paper/index_en.htm

Cowles, M.G. (2003), 'Non-state actors and false dichotomies', Journal of European Public Policy 10(1): 102-120.

Crawford, V.P. and J. Sobel (1982), 'Strategic information transmission', Econometrica 50(6): 1431-1451.

Dupuy, K., J. Ron and A. Prakash (2015), 'Who survived?', Review of International Political Economy 22(2): 419-456.

Dür, A. (2008), 'Interest groups in the European Union', West European Politics 31(6): 1212-1230.

Ebrahim, A. (2003), 'Accountability in practice: mechanisms for NGOs', World Development 31(5): 813-829.

Edwards, M. and D. Hulme (1996), Beyond the Magic Bullet, West Hartford, CT: Kumarian Press.

European Union Transparency Register (2012), 'Transparency Register Compliance Guidelines', third edition. http://ec.europa.eu/transparencyregister/info/your-organization/guidanceFInancial.do?locale=en.

Fowler, A. (1992), 'Distant obligations: speculations on NGO funding and the global market', Review of African Political Economy 55: 9-29.

Froelich, K.A. (1999), 'Diversification of revenue strategies', Nonprofit and Voluntary Sector Quarterly 28(3): 246-268.

Greenwood, J. (2007), 'Organized civil society and democratic legitimacy in the EU', British Journal of Political Science 37(2): 333-357.

- (2010), 'Regulating NGO participation in the EU', in J. Steffek and K. Hahn (eds), Evaluating Transnational NGOs, Chapter 9 Basingstoke: Palgrave Macmillan, pp. 200-219.

Greenwood, J. and D. Halpin (2007), 'The European Commission and public governance of interest groups in the European Union', Perspectives on European Politics and Society 8(2): 189-210.

Greenwood, J. and J. Dreger (2013), 'The Transparency Register', Interest Groups and Advocacy 2(2): 139-162.

Gronbjerg, K.A. (1993), Understanding Nonprofit Funding, San Francisco, CA: Jossey-Bass.

Haines, H. (1984), 'Black radicalization and the funding of civil rights', Social Problems 32: 31-43.

Halpin, D. (2006), 'The participatory and democratic potential and practice of interest groups', Public Administration 84(4): 919-940.

Hyndman, R. and G. Grunwald (2000), 'Generalized additive modeling of mixed distribution Markhov models with application to Melborne's rainfall', Australian and New Zealand Journal of Statistics 42(2): $145-158$.

ICNL (2012), 'NGO law monitor: Russia'. Retrieved 8 November 2012 from http://www.icnl.org/research/ monitor/russia.html

Jaeger, H. (2007), “'Global civil society” and the political depoliticization of global governance', International Political Sociology 1(3): 257-277.

Jenkins, J.C. (1987), 'Nonprofit organizations and policy advocacy', in W.W. Powell (ed.), The Nonprofit Sector: A Research Handbook, New Haven, CT: Yale University Press, pp. 296-320.

Joint Transparency Register Secretariat (2015), 'Transparency Register Implementing Guidelines'. http:/lec. europa.eu/transparencyregister/public/openFile.do?fileName=guidelines_en.pdf.

Kearns, K., D. Bell, B. Deem and L. McShane (2014), 'How nonprofit leaders evaluate funding sources', Nonprofit and Voluntary Sector Quarterly, 43: 121-143. 
Kerlin, J.A. (2006), 'US based international NGOs and federal government foreign assistance', in E.T. Boris and C.E. Steuerle (eds), Nonprofits and Government, Washington, DC: Urban Institute Press, pp. 373-398.

Klüver, H. and S. Saurugger (2013), 'Opening the black box', Interest Groups \& Advocacy 2(2): 185-202.

Kohler-Koch, B. and B. Finke (2007), 'The institutional shaping of EU-society relations', Journal of Civil Society 3(3): 205-221.

Lecy, J.D. and D.M. Van Slyke (2013), 'Nonprofit sector growth and density', Journal of Public Administration Research and Theory 23(1): 189-214.

Leech, B. (2006), 'Funding faction or buying silence?', The Policy Studies Journal 34(1): 17-35.

Lohmann, S. (1993), 'A signaling model of informative and manipulative political action', The American Political Science Review 87(2): 319-333.

Maddison, S. (2007), 'Silencing the critics'. The Age. Retrieved 19 March 2013 from http://www.theage. com.au/articles/2007/01/26/1169788690664.html?page $=6$

Mahoney, C. (2008), Brussels Versus the Beltway, Georgetown, TX: Georgetown University Press.

Mahoney, C. and M.J. Beckstrand (2011), 'Following the money', Journal of Common Market Studies 49(6): 1339-1361.

McAdam, D. (1982), Political Process and the Development of Black Insurgency, Chicago, IL: University of Chicago Press.

Mendelson, S. and J. Glenn (2002), The Power and Limits of NGOs, New York: Columbia University Press.

Mitchell, G. (2012), 'Strategic responses to resource dependence among transnational NGOs registered in the United States', Voluntas 25(1): 67-91.

Mosley, J.E. (2011), 'Institutionalization, privatization, and political opportunity', Nonprofit and Voluntary Sector Quarterly 40(3): 435-457.

- (2012), 'Keeping the lights on', JPART 22(4): 841-866.

Moulton, S. and A. Eckerd (2012), 'Preserving the publicness of the nonprofit sector', Nonprofit and Voluntary Sector Quarterly 41(4): 656-685.

Nelson, P. and E. Dorsey (2008), New Rights Advocacy, Washington, DC: Georgetown University Press.

Neumayr, M., U. Schneider and M. Meyer (2015), 'Public funding and its impact on nonprofit advocacy', Nonprofit and Voluntary Sector Quarterly 44(2): 297-318.

Onyx, J., B. Dalton, R. Melville, J. Casey and R. Banks (2008), 'Implications of government funding of advocacy for third-sector independence and exploration of alternative advocacy funding models', Australian Journal of Social Issues 43(4): 631-648.

Ostrander, S.A., I. Silver and D. McCarthy (2005), 'Mobilizing money strategically', in D.R. Faber and D. McCarthy (eds), Foundations for Social Change, Lanham, MD: Rowman \& Littlefield, pp. 271-290.

Pallas, C. and A. Uhlin (2014), 'Civil society influence on international organizations', Journal of Civil Society 10(2): 184-203.

Reimann, K. (2006), 'A view from the top', International Studies Quarterly 50(1): 45-67.

Ruggiano, N. and J. Taliaferro (2012), 'Resource dependency and agent theories', Journal of Policy Practice 11(4): 219-235.

Ryan, W.P., F.T. Miller and D. Weiss (2002), 'Government funding of nonprofit human-service organizations’. Unpublished manuscript, Rockefeller Brothers Fund, New York.

Salamon, L. (2002), 'Explaining nonprofit advocacy'. Working Paper No. 21, Johns Hopkins University, Institute for Policy Studies, Center for Civil Society Studies, Baltimore.

Salamon, L. and S. Wojciech Sokolowski and Associates (2004), Global Civil Society, Vol. II Bloomfield, NJ: Kumarian Press.

Sanchez Salgado, R. (2010), 'NGO structural adaptation to funding requirements and prospects for democracy', Global Society 24(4): 507-527.

- (2014), 'Rebalancing EU interest representation?', Journal of Common Market Studies 52(2): 337-353.

Saurugger, S. (2011), 'Interest representation and advocacy within the European Union', in B. Reinalda (ed.), The Ashgate Research Companion to Non-State Actors, Farnham: Ashgate, pp. 236-275. 
Schmid, H., M. Bar and R. Nirel (2008), 'Advocacy activities in nonprofit human service organizations', Nonprofit \& Voluntary Sector Quarterly 37(4): 581-602.

Seccombe, M. (2014), 'Brandis ties NGO funding to non-advocacy', The Saturday Paper, 26 July.

Smillie, I. (1996), 'Painting Canadian Roses Red', in M. Edwards and D. Hulme (eds), Beyond the Magic Bullet, West Hartford: Kumarian Press, pp. 187-197.

Smith, S.R. (1999), 'Government financing of nonprofit activity', in E.T. Boris and C.E. Steuerle (eds), Nonprofits and Government, Washington, DC: Urban Institute Press, pp. 177-210.

Smith, S.R. and K. Gronbjerg (2006), 'Scope and theory of government-nonprofit relations', in W. Powell and P. DiMaggio (eds), The Nonprofit Sector, New Haven, CT: Yale University Press, pp. 221-238.

Smith, S.R. and M. Lipsky (1993), Nonprofits for Hire, Cambridge, MA: Harvard University Press.

Smith, S.R. and R. Pekkanen (2012), 'Revisiting advocacy by nonprofit organizations', Voluntary Sector Review 3(1): 35-49.

Streeck, W. and P. Schmitter (1991), 'From national corporatism to transnational pluralism', Politics and Society 19(2): 133-164.

Steffek, J. and K. Hahn (eds) (2010), Evaluating Transnational NGOs, Basingstoke: Palgrave Macmillan.

Steffek, J., C. Kissling and P. Nanz (2008), Civil Society Participation in European and Global Governance., New York: Palgrave Macmillan.

Stroup, S.S. (2012), Borders Among Activists, Ithaca, NY: Cornell University Press.

Suarez, D. (2011), 'Collaboration and professionalization', Journal of Public Administration Research and Theory 21(2): 307-326.

Tallberg, J., T. Sommerer, T. Squatrito and C. Jönsson (2013), The Opening Up of International Organizations, Cambridge: Cambridge University Press.

Ullman, C. (1999), The Welfare State's Other Crisis, Indianapolis, IN: Indiana University Press.

Verbruggen, S., J. Christiaens and K. Milis (2011), 'Can resource dependence and coercive isomorphism explain nonprofit organizations' compliance with reporting standards?', Nonprofit and Voluntary Sector Quarterly 40(1): 5-32.

Warleigh, A. (2001), “'Europeanizing” civil society', Journal of Common Market Studies 39(4): 619-639.

Wells, R. (2001), 'Ensuring NGO independence in the new funding environment', Development in Practice 11(1): 73-85.

Wilson, F. (1983), 'Interest groups and politics in Western Europe', Comparative Politics 16(1): 105-123. 